\title{
Comparative pathogenesis of COVID-19, MERS, and SARS in a nonhuman primate model
}

\author{
Barry Rockx ${ }^{1 *}$, Thijs Kuiken', Sander Herfst ${ }^{1}$, Theo Bestebroer ${ }^{1}$, Mart M. Lamers ${ }^{1}$, Bas B. Oude Munnink ${ }^{1}$, \\ Dennis de Meulder', Geert van Amerongen ${ }^{2}$, Judith van den Brand ${ }^{1}+$, Nisreen M. A. Okba', Debby Schipper', \\ Peter van Run ${ }^{1}$, Lonneke Leijten ${ }^{1}$, Reina Sikkema ${ }^{1}$, Ernst Verschoor ${ }^{3}$, Babs Verstrepen ${ }^{3}$, Willy Bogers ${ }^{3}$, Jan \\ Langermans $^{4,5}$, Christian Drosten ${ }^{6}$, Martje Fentener van Vlissingen ${ }^{7}$, Ron Fouchier ${ }^{1}$, Rik de Swart ${ }^{1}$, Marion \\ Koopmans ${ }^{1}$, Bart L. Haagmans ${ }^{1 *}$
}

${ }^{1}$ Department of Viroscience, Erasmus University Medical Center, Rotterdam, Netherlands. ${ }^{2}$ Viroclinics Xplore, Schaijk, Netherlands. ${ }^{3}$ Department of Virology, Biomedical Primate Research Centre, Rijswijk, Netherlands. ${ }^{4}$ Animal Science Department, Biomedical Primate Research Centre, Rijswijk, Netherlands. ${ }^{5}$ Population Health Sciences, Unit Animals in Science and Society, Faculty of Veterinary Medicine, Utrecht University, Netherlands. ${ }^{6}$ Institute of Virology, Charité-Universitätsmedizin, Berlin, Germany. ${ }^{7}$ Erasmus Laboratory Animal Science Center, Erasmus University Medical Center, Rotterdam, Netherlands.

*Corresponding author. E-mail:b.rockx@erasmusmc.nl (B.R.); b.haagmans@erasmusmc.nl (B.L.H.)

†Present address: Division of Pathology, Faculty of Veterinary Medicine, Utrecht University, Utrecht, Netherlands

The current pandemic coronavirus, SARS-CoV-2, was recently identified in patients with an acute respiratory syndrome, COVID-19. To compare its pathogenesis with that of previously emerging coronaviruses, we inoculated cynomolgus macaques with SARS-CoV-2 or MERS-CoV and compared the pathology and virology with historical reports of SARS-CoV infections. In SARS-CoV-2-infected macaques, virus was excreted from nose and throat in the absence of clinical signs, and detected in type I and II pneumocytes in foci of diffuse alveolar damage and in ciliated epithelial cells of nasal, bronchial, and bronchiolar mucosae. In SARS-CoV-infection, lung lesions were typically more severe, while they were milder in MERS-CoV infection, where virus was detected mainly in type II pneumocytes. These data show that SARS-CoV-2 causes COVID-19-like disease in macaques, and provides a new model to test preventive and therapeutic strategies.

Following the first reports of an outbreak of an acute respiratory syndrome in China in December 2019, a novel coronavirus, SARS-CoV-2, was identified (1,2). As of March 14, 2020, over 140,000 cases were reported worldwide with over 5,400 deaths, surpassing the combined number of cases and deaths of two previously emerging coronaviruses, SARS-CoV and MERS-CoV (3). The disease caused by this virus, COVID-19, is characterized by a range of symptoms, including fever, cough, dyspnoea and myalgia in most cases (2). In severe cases, bilateral lung involvement with ground-glass opacity is the most common chest computed tomography (CT) finding (4). Similarly to the $2002 / 2003$ outbreak of SARS, the severity of COVID-19 disease is associated with increased age and/or a comorbidity, although severe disease is not limited to these risk groups (5). However, despite the large number of cases and deaths, limited information is available on the pathogenesis of this virus infection. Two reports on the histological examination of the lungs of three patients showed bilateral diffuse alveolar damage (DAD), pulmonary edema and hyaline membrane formation, indicative of acute respiratory distress syndrome (ARDS), as well as characteristic syncytial cells in the alveolar lumen $(6,7)$, similar to findings during the 2002/2003 outbreak of SARS-CoV (8). The pathogenesis of SARS-CoV infection was previously studied in a non- human primate model (cynomolgus macaques) where aged animals were more likely to develop disease (9-13). In the current study, SARS-CoV-2 infection was characterized in the same animal model and compared with infection with MERS$\mathrm{CoV}$ and historical data on $\operatorname{SARS}-\mathrm{CoV}(9,10,12)$.

First, two groups of four cynomolgus macaques (both young adult (young), 4-5 years of age; and old adult (aged), 15-20 years of age) were inoculated by a combined intratracheal (IT) and intranasal (IN) route with a SARS-CoV-2 strain from a German traveler returning from China. No overt clinical signs were observed in any of the infected animals, except for a serous nasal discharge in one aged animal on day 14 post inoculation (p.i.). No significant weight loss was observed in any of the animals during the study. By day 14 p.i. all remaining animals seroconverted as revealed by the presence of SARS-CoV-2 specific antibodies against the virus S1 domain and nucleocapsid proteins in their sera (Fig. S1).

As a measure of virus shedding, nasal, throat and rectal swabs were assayed for virus by RT-qPCR and virus culture. In nasal swabs, detection of SARS-CoV-2 RNA peaked by day 2 p.i. in young animals, by day 4 p.i. in aged animals, was detected up to at least day 8 p.i. in two out of four animals and up to day 21 p.i. in one out of four animals (Fig. 1A). Overall, higher levels of SARS-CoV-2 RNA were detected in nasal 
swabs of aged animals compared with young animals. SARSCoV-2 RNA detection in throat swabs peaked at day 1 p.i. in young and day 4 p.i. in aged animals and decreased more rapidly over time by comparison with the nasal swabs, but could still be detected intermittently up to day 10 p.i. (Fig. 1B). Low levels of infectious virus were cultured from throat and nasal swabs up to day 2 and 4 , respectively (Table S1). In support of virus shedding by these animals, environmental sampling was performed to determine potential contamination of surfaces. Environmental sampling indicated the presence of low levels of SARS-CoV-2 RNA on surfaces through both direct contact (hands) and indirect contamination within the isolator (Table S2). SARS-CoV-2 RNA was only detected in a rectal swab from one animal on day 14 p.i. and no viral RNA was detected in whole blood at any time point throughout the study.

On autopsy of four macaques on day 4 p.i., two had foci of pulmonary consolidation in the lungs (Fig. 2A). One animal (aged: 17 years) showed consolidation in the right middle lobe, representing less than $5 \%$ of the lung tissue. A second animal (young: 5 years) had two foci in the left lower lobe, representing about $10 \%$ of the lung tissue (Fig. 2A). The consolidated lung tissue was well-circumscribed, red-purple, level, and less buoyant than normal. The other organs in these two macaques, as well as the respiratory tract and other organs of the other two animals were normal.

Virus replication was assessed by RT-qPCR on day 4 p.i. in tissues from the respiratory, digestive, urinary, and cardiovascular tracts, from endocrine and central nervous systems, as well as from various lymphoid tissues. Virus replication was primarily restricted to the respiratory tract (nasal cavity, trachea, bronchi and lung lobes) with highest levels of SARS-CoV-2 RNA in lungs (Fig. 1C). Interestingly, in three out of four animals, SARS-CoV-2 RNA was also detected in ileum and tracheo-bronchial lymph nodes (Fig. 1C).

The main histological lesion in the consolidated pulmonary tissues of both the young and aged animals involved the alveoli and bronchioles and consisted of areas with acute or more advanced DAD (Fig. 2B). In these areas, the lumina of alveoli and bronchioles were variably filled with protein-rich edema fluid, fibrin, and cellular debris, alveolar macrophages, and fewer neutrophils and lymphocytes (Fig. 2C-E). There was epithelial necrosis with extensive loss of epithelium from alveolar and bronchiolar walls. Hyaline membranes were present in a few damaged alveoli. In areas with more advanced lesions, the alveolar walls were moderately thickened and lined by cuboidal epithelial cells (type II pneumocyte hyperplasia), and the alveolar lumina were empty. Alveolar and bronchiolar walls were thickened by edema fluid, mononuclear cells, and neutrophils. There were aggregates of lymphocytes around small pulmonary vessels. Moderate numbers of lymphocytes and macrophages were present in the lamina propria and submucosa of the bronchial walls, and a few neutrophils in the bronchial epithelium. Regeneration of epithelium was seen in some bronchioles, visible as an irregular layer of squamous to high cuboidal epithelial cells with hyperchromatic nuclei. There were occasional multinucleated giant cells (syncytia) free in the lumina of bronchioles and alveoli (Fig. 2F), and, based on positive pankeratin staining and negative CD68 staining, these appeared to originate from epithelial cells (Fig. $2 \mathrm{~F}$, inset).

SARS-CoV-2 antigen expression was detected in moderate numbers of type I pneumocytes and a few type II pneumocytes within foci of DAD (Fig. 2G, Fig. 2H, fig. S2). The pattern of staining was similar to that in lung tissue from SARS-CoVinfected macaques (positive control). SARS-CoV-2 antigen expression was not observed in any of the syncytia. In addition, SARS-CoV-2 antigen expression was detected in non-lesional tissues of all lung lobes in three out of four macaques (both young and one aged) in a few type I and II pneumocytes, bronchial ciliated epithelial cells, and bronchiolar ciliated epithelial cells. The other aged macaque, without virological or pathological evidence of SARS-CoV-2 infection in the lungs, did have SARS-CoV-2 antigen expression in ciliated epithelial cells of nasal septum (Fig. 2I), nasal concha, and palatum molle, in absence of associated histopathological changes. No SARS-CoV-antigen expression was detected in other sampled tissues, including brain and intestine .

To assess the severity of infection with SARS-CoV-2 compared with MERS-CoV, young cynomolgus macaques (3-5 years of age) were inoculated with MERS-CoV via the IN and IT route. All animals remained free of clinical signs. At day 21 p.i., all remaining animals $(n=2)$ seroconverted as revealed by the presence of MERS-CoV specific antibodies in their sera by ELISA (Fig. S3).

MERS-CoV RNA was detected in nasal (Fig. 3A) and throat swabs (Fig. 3B) on days 1-11 p.i., with peaks on days 1 and 2 p.i., respectively. Low levels (between 1-85 TCID50 equivalent/mL) of MERS-CoV RNA were detected in rectal swabs on days 2 and 3 p.i.

At autopsy of four macaques at day 4 p.i., three animals had foci of pulmonary consolidation, characterized by slightly depressed areas in the lungs, representing less than $5 \%$ of the lung tissue (Table 1). Similar to SARS-CoV-2 infection in both young and aged animals, on day 4 p.i., MERSCoV RNA was primarily detected in the respiratory tract of inoculated animals (Fig. 3C). Infectious virus titers were comparable to SARS-CoV-2, but lower compared to SARS-CoV infection of young macaques (Table 1). In addition, MERS-CoV RNA was detected in the spleen (Table 1).

Consistent with the presence of virus in the lower respiratory tract at day 4 p.i., histopathological changes characteristic for $\mathrm{DAD}$ were observed in the lungs of inoculated animals (Fig. 3D). The alveolar septa were thickened owing 
to infiltration of neutrophils and macrophages, and moderate type II pneumocyte hyperplasia and hypertrophy. In the alveolar lumina, there were elevated alveolar macrophages and some edema fluid containing fibrin and some neutrophils (Fig. 3D). Few syncytial cells were seen in the alveolar lumina. Interestingly, MERS-CoV antigen was not detected in tissues on day 4 p.i. in any part of the respiratory tract. We therefore sampled four young macaques at day 1 p.i. At this time we observed. multifocal expression of viral antigen, predominantly in type II pneumocytes and occasionally in type I pneumocytes, bronchiolar and bronchial epithelial cells and some macrophages (Fig. 3D).

In summary, we inoculated young and aged cynomolgus macaques with a low passage clinical isolate of SARS-CoV-2, which resulted in productive infection in the absence of overt clinical signs. Recent studies in human cases have shown that presymptomatic and asymptomatic cases can also shed virus $(14,15)$. Increased age did not affect disease outcome, but there was prolonged viral shedding in the upper respiratory tract of aged animals. Prolonged shedding has been observed in both SARS-CoV-2 and SARS-CoV patients $(16,17)$. Interestingly, SARS-CoV-2 shedding in our asymptomatic model, peaked early in the course of infection, similar to what is seen in symptomatic patients (16). Also, SARS-CoV-2 antigen was detected in ciliated epithelial cells of nasal mucosae at day 4 p.i., which was not seen for SARS-CoV (10) or MERS-CoV infections (this manuscript) in this animal model. Viral tropism for the nasal mucosa fits with efficient respiratory transmission, as has been seen for influenza A virus (18). This early peak in virus shedding for SARS-CoV-2 is similar to influenza virus shedding (19) and may explain why case detection and isolation may not be as effective for SARS-CoV-2 as it was for the control of SARS-CoV (20). SARS-CoV-2 was primarily detected in tissues of the respiratory tract, however SARS-CoV2 RNA was also detectable in other tissues such as intestines, in line with a recent report (21). Similar results regarding viral shedding and tissue and cell tropism were recently also reported following SARS-CoV-2 inoculation in rhesus macaques. However, unlike in our model, SARS-CoV-2 infection in rhesus macaques does result in transient respiratory disease and weight loss $(22,23)$.

Two out of four animals had foci of DAD on day 4 p.i. The colocalisation of SARS-CoV-2-antigen expression and DAD provides strong evidence that SARS-CoV-2 infection caused this lesion. The histological character of the DAD, including alveolar and bronchiolar epithelial necrosis, alveolar edema, hyaline membrane formation, and accumulation of neutrophils, macrophages and lymphocytes, corresponds with the limited pathological analyses of human COVID-19 cases $(6,7)$. In particular, the presence of syncytia in the lung lesions is characteristic of respiratory coronavirus infections. Whereas MERS-CoV primarily infects type II pneumocytes in cynomolgus macaques, both SARS-CoV and SARS-CoV-2 also infect type I pneumocytes. Injury to type I pneumocytes can result in pulmonary edema, and formation of hyaline membranes (24), which may explain why hyaline membrane formation is a hallmark for SARS and COVID-19 $(7,10)$, but not frequently reported for MERS $(25,26)$.

These data show that cynomolgus macaques are permissive to SARS-CoV-2 infection, shed virus for a prolonged period of time and display COVID-19-like disease. In this nonhuman primate model, SARS-CoV-2 replicates efficiently in respiratory epithelial cells throughout the respiratory tract, including nasal cavity, bronchi, bronchioles, and alveoli. Replication in the upper respiratory tract fits with efficient transmission between hosts, while replication in the lower respiratory tract fits with the development of lung disease. An in-depth comparison of infection with SARS-CoV, MERSCoV and SARS-CoV-2 in this model may identify key pathways in the pathogenesis of these emerging viruses. This study provides a novel infection model which will be critical in the evaluation and licensure of preventive and therapeutic strategies against SARS-CoV-2 infection for use in humans, as well as evaluating the efficacy of repurposing species specific existing treatments, such as pegylated interferon (12).

\section{REFERENCES AND NOTES}

1. J. F. Chan, S. Yuan, K.-H. Kok, K. K.-W. To, H. Chu, J. Yang, F. Xing, J. Liu, C. C.-Y. Yip, R. W.-S. Poon, H.-W. Tsoi, S. K.-F. Lo, K.-H. Chan, V. K.-M. Poon, W.-M. Chan, J. D. Ip, J.-P. Cai, V. C.-C. Cheng, H. Chen, C. K.-M. Hui, K.-Y. Yuen, A familial cluster of pneumonia associated with the 2019 novel coronavirus indicating person-toperson transmission: A study of a family cluster. Lancet 395, 514-523 (2020). doi:10.1016/S0140-6736(20)30154-9 Medline

2. C. Huang, Y. Wang, X. Li, L. Ren, J. Zhao, Y. Hu, L. Zhang, G. Fan, J. Xu, X. Gu, Z. Cheng, T. Yu, J. Xia, Y. Wei, W. Wu, X. Xie, W. Yin, H. Li, M. Liu, Y. Xiao, H. Gao, L. Guo, J. Xie, G. Wang, R. Jiang, Z. Gao, Q. Jin, J. Wang, B. Cao, Clinical features of patients infected with 2019 novel coronavirus in Wuhan, China. Lancet 395, 497506 (2020). doi:10.1016/S0140-6736(20)30183-5 Medline

3. E. Mahase, Coronavirus covid-19 has killed more people than SARS and MERS combined, despite lower case fatality rate. BMJ 368, m641 (2020). doi:10.1136/bmi.m641 Medline

4. H. Shi, X. Han, N. Jiang, Y. Cao, O. Alwalid, J. Gu, Y. Fan, C. Zheng, Radiological findings from 81 patients with COVID-19 pneumonia in Wuhan, China: A descriptive study. Lancet Infect. Dis. 20, 425-434 (2020). doi:10.1016/S14733099(20)30086-4 Medline

5. N. Chen, M. Zhou, X. Dong, J. Qu, F. Gong, Y. Han, Y. Qiu, J. Wang, Y. Liu, Y. Wei, J. Xia, T. Yu, X. Zhang, L. Zhang, Epidemiological and clinical characteristics of 99 cases of 2019 novel coronavirus pneumonia in Wuhan, China: A descriptive study. Lancet 395, 507-513 (2020). doi:10.1016/S0140-6736(20)30211-7 Medline

6. Z. Xu, L. Shi, Y. Wang, J. Zhang, L. Huang, C. Zhang, S. Liu, P. Zhao, H. Liu, L. Zhu, Y. Tai, C. Bai, T. Gao, J. Song, P. Xia, J. Dong, J. Zhao, F.-S. Wang, Pathological findings of COVID-19 associated with acute respiratory distress syndrome. Lancet Respir. Med. 8, 420-422 (2020). doi:10.1016/S2213-2600(20)30076-X Medline

7. S. Tian, W. Hu, L. Niu, H. Liu, H. Xu, S.-Y. Xiao, Pulmonary pathology of early-phase 2019 novel coronavirus (COVID-19) pneumonia in two patients with lung cancer J. Thorac. Oncol. S1556-0864(20)30132-5 (2020). doi:10.1016/i.jtho.2020.02.010 Medline

8. J. M. Nicholls, L. L. M. Poon, K. C. Lee, W. F. Ng, S. T. Lai, C. Y. Leung, C. M. Chu, P. K. Hui, K. L. Mak, W. Lim, K. W. Yan, K. H. Chan, N. C. Tsang, Y. Guan, K. Y. Yuen, J. S. Peiris, Lung pathology of fatal severe acute respiratory syndrome. Lancet 361 1773-1778 (2003). doi:10.1016/S0140-6736(03)13413-7 Medline

9. R. A. Fouchier, T. Kuiken, M. Schutten, G. van Amerongen, G. J. J. van Doornum, B. 
G. van den Hoogen, M. Peiris, W. Lim, K. Stöhr, A. D. M. E. Osterhaus, Koch's postulates fulfilled for SARS virus. Nature 423, 240 (2003). doi:10.1038/423240a Medline

10. T. Kuiken, R. A. M. Fouchier, M. Schutten, G. F. Rimmelzwaan, G. van Amerongen, D. van Riel, J. D. Laman, T. de Jong, G. van Doornum, W. Lim, A. E. Ling, P. K. S. Chan, J. S. Tam, M. C. Zambon, R. Gopal, C. Drosten, S. van der Werf, N. Escriou, J.-C. Manuguerra, K. Stöhr, J. S. M. Peiris, A. D. M. E. Osterhaus, Newly discovered coronavirus as the primary cause of severe acute respiratory syndrome. Lancet 362, 263-270 (2003). doi:10.1016/S0140-6736(03)13967-0 Medline

11. S. L. Smits, A. de Lang, J. M. A. van den Brand, L. M. Leijten, W. F. van IJcken, M. J. C. Eijkemans, G. van Amerongen, T. Kuiken, A. C. Andeweg, A. D. M. E. Osterhaus, B. L. Haagmans, Exacerbated innate host response to SARS-CoV in aged nonhuman primates. PLOS Pathog. 6, el000756 (2010). doi:10.1371/journal.ppat.1000756 Medline

12. B. L. Haagmans, T. Kuiken, B. E. Martina, R. A. M. Fouchier, G. F. Rimmelzwaan, G. van Amerongen, D. van Riel, T. de Jong, S. Itamura, K.-H. Chan, M. Tashiro, A. D. M. E. Osterhaus, Pegylated interferon-alpha protects type 1 pneumocytes against SARS coronavirus infection in macaques. Nat. Med. 10, 290-293 (2004). doi:10.1038/nm1001 Medline

13. B. Rockx, F. Feldmann, D. Brining, D. Gardner, R. LaCasse, L. Kercher, D. Long, R. Rosenke, K. Virtaneva, D. E. Sturdevant, S. F. Porcella, J. Mattoon, M. Parnell, R. S. Baric, H. Feldmann, Comparative pathogenesis of three human and zoonotic SARS-CoV strains in cynomolgus macaques. PLOS ONE 6, e18558 (2011). doi:10.1371/journal.pone.0018558 Medline

14. C. Li, F. Ji, L. Wang, L. Wang, J. Hao, M. Dai, Y. Liu, X. Pan, J. Fu, L. Li, G. Yang, J. Yang, X. Yan, B. Gu, Asymptomatic and Human-to-Human Transmission of SARSCoV-2 in a 2-Family Cluster, Xuzhou, China. Emerg. Infect. Dis. 26 (2020). doi:10.3201/eid2607.200718 Medline

15. A. Kimball, K. M. Hatfield, M. Arons, A. James, J. Taylor, K. Spicer, A. C. Bardossy, L. P. Oakley, S. Tanwar, Z. Chisty, J. M. Bell, M. Methner, J. Harney, J. R. Jacobs, C. M. Carlson, H. P. McLaughlin, N. Stone, S. Clark, C. Brostrom-Smith, L. C. Page, M. Kay, J. Lewis, D. Russell, B. Hiatt, J. Gant, J. S. Duchin, T. A. Clark, M. A. Honein, S. C. Reddy, J. A. Jernigan, A. Baer, L. M. Barnard, E. Benoliel, M. S. Fagalde, J. Ferro, H. G. Smith, E. Gonzales, N. Hatley, G. Hatt, M. Hope, M. Huntington-Frazier, V. Kawakami, J. L. Lenahan, M. D. Lukoff, E. B. Maier, S. McKeirnan, P. Montgomery, J. L. Morgan, L. A. Mummert, S. Pogosjans, F. X. Riedo, L. Schwarcz, D. Smith, S. Stearns, K. J. Sykes, H. Whitney, H. Ali, M. Banks, A. Balajee, E. J. Chow, B. Cooper, D. W. Currie, J. Dyal, J. Healy, M. Hughes, T. M. McMichael, L. Nolen, C. Olson, A. K. Rao, K. Schmit, N. G. Schwartz, F. Tobolowsky, R. Zacks, S. Zane; Public Health - Seattle \& King County; CDC COVID-19 Investigation Team, Asymptomatic and Presymptomatic SARS-CoV-2 Infections in Residents of a Long-Term Care Skilled Nursing Facility - King County, Washington, March 2020. MMWR Morb. Mortal. Wkly. Rep. 69, 377-381 (2020). doi:10.15585/mmwr.mm6913el Medline

16. L. Zou, F. Ruan, M. Huang, L. Liang, H. Huang, Z. Hong, J. Yu, M. Kang, Y. Song, J. Xia, Q. Guo, T. Song, J. He, H.-L. Yen, M. Peiris, J. Wu, SARS-CoV-2 Viral Load in Upper Respiratory Specimens of Infected Patients. N. Engl. J. Med. 382, 11771179 (2020). doi:10.1056/NEJMc2001737 Medline

17. J. S. Peiris, C. M. Chu, V. C. C. Cheng, K. S. Chan, I. F. N. Hung, L. L. M. Poon, K. I. Law, B. S. F. Tang, T. Y. W. Hon, C. S. Chan, K. H. Chan, J. S. C. Ng, B. J. Zheng, W. L. Ng, R. W. M. Lai, Y. Guan, K. Y. Yuen; HKU/UCH SARS Study Group, Clinical progression and viral load in a community outbreak of coronavirus-associated SARS pneumonia: A prospective study. Lancet 361, 1767-1772 (2003). doi:10.1016/S0140-6736(03)13412-5 Medline

18. M. Richard, J. M. A. van den Brand, T. M. Bestebroer, P. Lexmond, D. de Meulder, R. A. M. Fouchier, A. C. Lowen, S. Herfst, Influenza A viruses are transmitted via the air from the nasal respiratory epithelium of ferrets. Nat. Commun. 11, 766 (2020). doi:10.1038/s41467-020-14626-0 Medline

19. C. C. Li, L. Wang, H.-L. Eng, H.-L. You, L.-S. Chang, K.-S. Tang, Y.-J. Lin, H.-C. Kuo, I.-K. Lee, J.-W. Liu, E.-Y. Huang, K. D. Yang, Correlation of pandemic (H1N1) 2009 viral load with disease severity and prolonged viral shedding in children. Emerg. Infect. Dis. 16, 1265-1272 (2010). doi:10.3201/eid1608.091918 Medline

20. X. Pang, Z. Zhu, F. Xu, J. Guo, X. Gong, D. Liu, Z. Liu, D. P. Chin, D. R. Feikin, Evaluation of control measures implemented in the severe acute respiratory syndrome outbreak in Beijing, 2003. JAMA 290, 3215-3221 (2003). doi:10.1001/jama.290.24.3215 Medline

21. F. Xiao, M. Tang, X. Zheng, Y. Liu, X. Li, H. Shan, Evidence for gastrointestinal infection of SARS-CoV-2. Gastroenterology S0016-5085(20)30282-1 (2020). doi:10.1053/i.gastro.2020.02.055 Medline

22. W. D. Linlin Bao et al., Reinfection could not occur in SARS-CoV-2 infected rhesus macaques. bioRxiv 2020.03.13.990226 https://doi.org/10.1101/2020.03.13.990226.

23. V. J. Munster et al., Respiratory disease and virus shedding in rhesus macaques inoculated with SARS-CoV-2. bioRxiv 2020.03.21.001628 (2020). https://doi.org/10.1101/2020.03.21.001628.

24. L. B. Ware, M. A. Matthay, The acute respiratory distress syndrome. N. Engl. J. Med. 342, 1334-1349 (2000). doi:10.1056/NEJM200005043421806 Medline

25. W. J. Shieh, C.-H. Hsiao, C. D. Paddock, J. Guarner, C. S. Goldsmith, K. Tatti, M. Packard, L. Mueller, M.-Z. Wu, P. Rollin, I.-J. Su, S. R. Zaki, Immunohistochemical, in situ hybridization, and ultrastructural localization of SARS-associated coronavirus in lung of a fatal case of severe acute respiratory syndrome in Taiwan. Hum. Pathol. 36, 303-309 (2005). doi:10.1016/i.humpath.2004.11.006 Medline

26. D. L. Ng, F. Al Hosani, M. K. Keating, S. I. Gerber, T. L. Jones, M. G. Metcalfe, S. Tong, Y. Tao, N. N. Alami, L. M. Haynes, M. A. Mutei, L. Abdel-Wareth, T. M. Uyeki, D. L. Swerdlow, M. Barakat, S. R. Zaki, Clinicopathologic, Immunohistochemical, and Ultrastructural Findings of a Fatal Case of Middle East Respiratory Syndrome Coronavirus Infection in the United Arab Emirates, April 2014. Am. J. Pathol. 186, 652-658 (2016). doi:10.1016/i.aipath.2015.10.024 Medline

27. V. S. Raj, H. Mou, S. L. Smits, D. H. W. Dekkers, M. A. Müller, R. Dijkman, D. Muth, J. A. A. Demmers, A. Zaki, R. A. M. Fouchier, V. Thiel, C. Drosten, P. J. M. Rottier, A. D. M. E. Osterhaus, B. J. Bosch, B. L. Haagmans, Dipeptidyl peptidase 4 is a functional receptor for the emerging human coronavirus-EMC. Nature 495, 251254 (2013). doi:10.1038/nature12005 Medline

28. B. L. Haagmans, J. M. A. van den Brand, L. B. Provacia, V. S. Raj, K. J. Stittelaar, S. Getu, L. de Waal, T. M. Bestebroer, G. van Amerongen, G. M. G. M. Verjans, R. A. M. Fouchier, S. L. Smits, T. Kuiken, A. D. M. E. Osterhaus, Asymptomatic Middle East respiratory syndrome coronavirus infection in rabbits. J. Virol. 89, 6131-6135 (2015). doi:10.1128/JVI.00661-15 Medline

29. V. M. Corman, O. Landt, M. Kaiser, R. Molenkamp, A. Meijer, D. K. W. Chu, T. Bleicker, S. Brünink, J. Schneider, M. L. Schmidt, D. G. J. C. Mulders, B. L. Haagmans, B. van der Veer, S. van den Brink, L. Wijsman, G. Goderski, J.-L. Romette, J. Ellis, M. Zambon, M. Peiris, H. Goossens, C. Reusken, M. P. G. Koopmans, C. Drosten, Detection of 2019 novel coronavirus (2019-nCoV) by realtime RT-PCR. Euro Surveill. 25, 25 (2020). doi:10.2807/15607917.ES.2020.25.3.2000045 Medline

\section{ACKNOWLEDGMENTS}

We thank L. de Meulder, A. van der Linden, I. Chestakova and F. van der Panne for technical assistance. Y. Kap, D. Akkermans, V. Vaes, M. Sommers, F. Meijers for assistance with the animal studies. Funding: This research is (partly) financed by the NWO Stevin Prize awarded to M.K. by the Netherlands Organisation for Scientific Research (NWO), H2020 grant agreement 874735 - VEO to M.K., $\mathrm{NIH/NIAID}$ contract HHSN272201400008C to R.F., and H2O2O grant agreement 101003651 - MANCO to B.H. Author contributions: Conceptualization, B.R., T.K., R.F., M.K., RdS, M.F. B.H.; investigation, B.R., T.K., S.H., T.B., M.L., D.d.M., G.v.A., J.v.d.B., N.O., D.S., P.v.R., L.L.; resources, B.H., C.D. E.V., B.V., J.L. supervision, B.R. and B.H.; writing, original draft, B.R., T.K. and B.H.; writingreview and editing, all authors; funding acquisition: S.H., B.H., R.F. and M.K. Animal welfare: Research was conducted in compliance with the Dutch legislation for the protection of animals used for scientific purposes (2014, implementing EU Directive 2010/63) and other relevant regulations. The licensed establishment where this research was conducted (Erasmus MC) has an approved OLAW Assurance \# A5051-01. Research was conducted under a project license from the Dutch competent authority and the study protocol (\#174312) was approved by the institutional Animal Welfare Body. Competing interests: TB, RF and BH are listed as an inventor on a patent application related to MERS-coronavirus diagnostics, therapy and vaccines. Other authors declare no competing interests. Data and materials availability: All data are available in the main text or the supplementary materials. This work is licensed under a Creative Commons Attribution 4.0 International (CC BY 4.0) license, which 
permits unrestricted use, distribution, and reproduction in any medium,

provided the original work is properly cited. To view a copy of this license, visit https://creativecommons. org/licenses/by/4.0/. This license does not apply to

figures/photos/artwork or other content included in the article that is credited to a third party; obtain authorization from the rights holder before using such material.

\section{SUPPLEMENTARY MATERIALS}

science.sciencemag.org/cgi/content/full/science.abb7314/DC1

Materials and Methods

Figs. S1 to S3

Tables S1 and S2

References (27-29)

MDAR Reproducibility Checklist

15 March 2020; accepted 15 April 2020

Published online 17 April 2020

10.1126/science.abb7314 


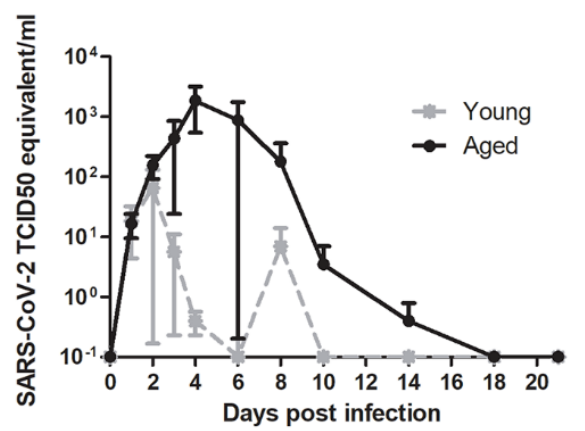

B

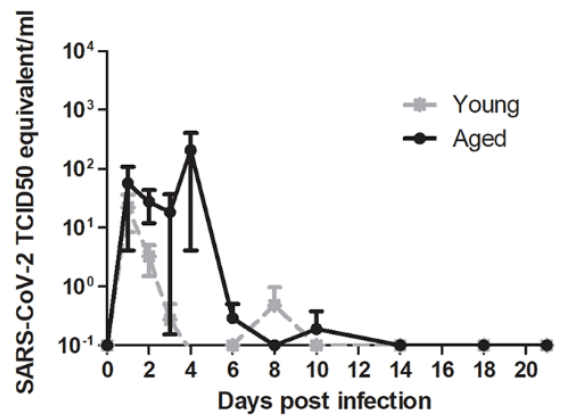

C

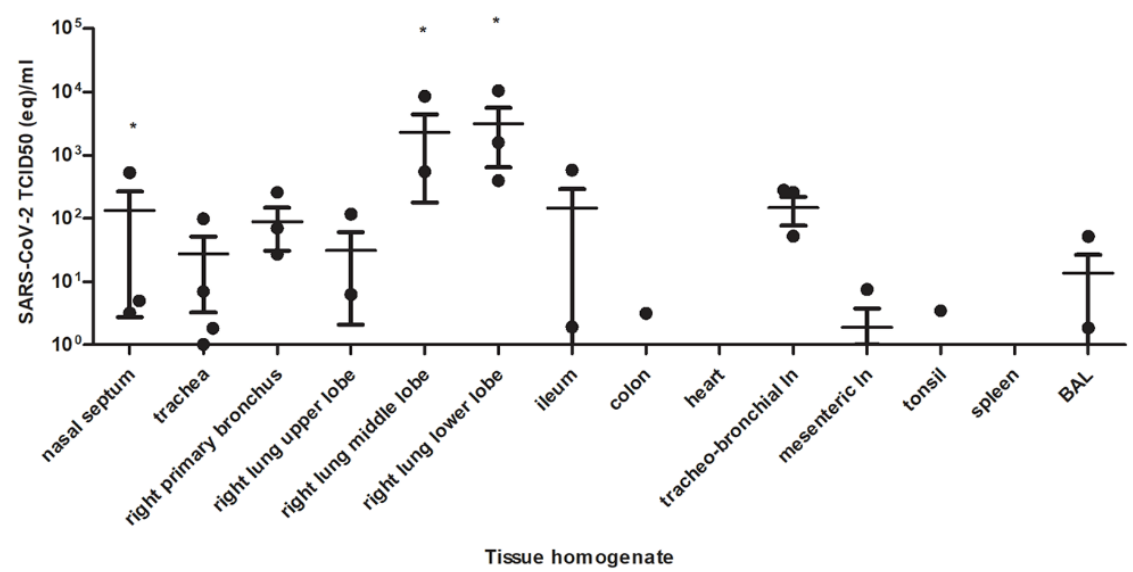

Fig. 1. Virus shedding and virus detection in organs of SARS-CoV-2 inoculated cynomolgus macaques. Viral RNA was detected in nasal (A) and throat (B) swabs and tissues (C) of SARS-CoV-2 infected animals by RT-qPCR. Samples from four animals (days 1-4) or two animals (days $>4$ ) per group were tested. The error bars represent the standard error of the mean. Virus was detected in tissues from two young, and two aged animals on day 4 by RT-qPCR. * = infectious virus was isolated. 

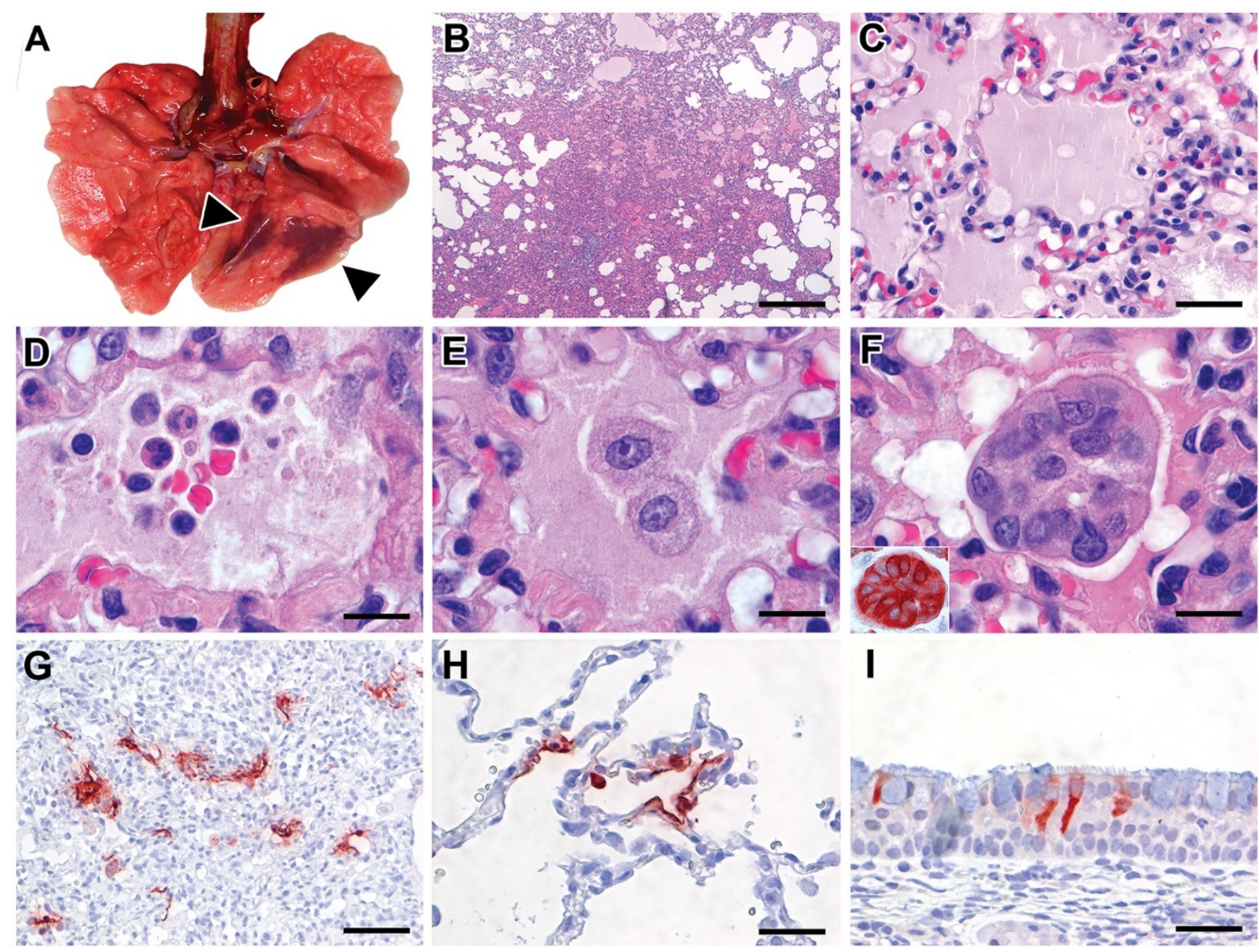

I

Fig. 2. Characteristic pathological changes and virus antigen expression in the lungs of SARSCoV-2-inoculated cynomolgus macaques. (A) Two foci of pulmonary consolidation in the left lower lung lobe (arrowheads). (B) Area of pneumonia (HE, bar indicates $0.5 \mathrm{~cm}$ ). (C) Edema fluid in alveolar lumina (HE, bar indicates $25 \mu \mathrm{m}$ ). (D) Neutrophils, as well as erythrocytes, fibrin, and cell debris, in an alveolar lumen flooded by edema fluid (HE, bar indicates $10 \mu \mathrm{m}$ ). (E) Mononuclear cells, either type II pneumocytes or alveolar macrophages, in an alveolar lumen flooded by edema fluid (HE, bar indicates $10 \mu \mathrm{m}$ ). (F) Syncytium in an alveolar lumen (HE, 100X objective). Inset: Syncytium expresses keratin, indicating epithelial cell origin (IHC for pankeratin AE1/AE3, bar indicates $10 \mu m$ ). (G) SARS-CoV-2 antigen expression is colocalized with areas of diffuse alveolar damage (IHC for SARS-CoV-nucleocapsid, bar indicates $50 \mu \mathrm{m}$ ). (H) Type I (flat) and type II (cuboidal) pneumocytes in affected lung tissue express SARS-CoV-2 antigen (IHC for SARS-CoV-nucleocapsid, bar indicates $25 \mu \mathrm{m}$ ). (I) Ciliated columnar epithelial cells of respiratory mucosa in nasal cavity express SARSCoV-2 antigen (IHC for SARS-CoV-nucleocapsid, bar indicates $25 \mu \mathrm{m}$ ). 
A

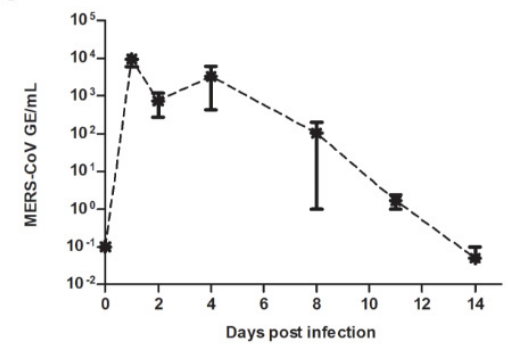

C

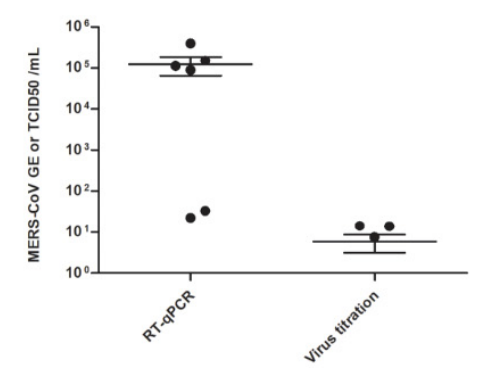

B

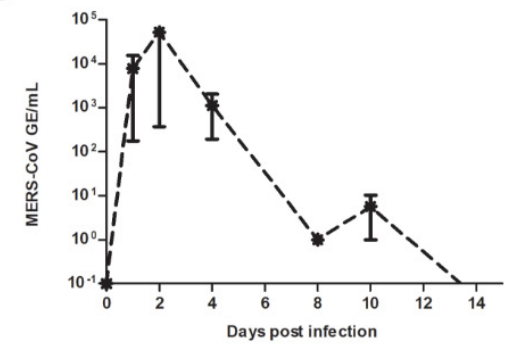

D

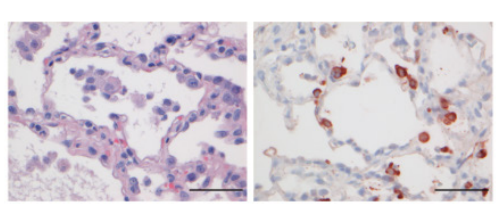

Fig. 3. Virus shedding and virus detection in organs of MERSCoV inoculated cynomolgus macaques. Viral RNA was detected in nasal (A) and throat (B) swabs and tissues (C) of MERS-CoV infected animals by RT-qPCR. Samples from four animals per group were tested. The error bars represent the standard error of the mean. Virus was detected in tissues on day 4 by RT-qPCR. Histopathological changes (D; left picture) with hypertrophic and hyperplastic type II pneumocytes in the alveolar septa and increased numbers of alveolar macrophages in the alveolar lumina and virus antigen expression (right picture) in type II pneumocytes, bar indicates $50 \mu \mathrm{m}$. 
Table 1. Comparative pathogenesis of SARS-CoV-2, MERS-CoV, and SARS-CoV infections in cynomolgus macaques.

\begin{tabular}{|c|c|c|c|c|c|c|c|c|c|c|c|c|c|}
\hline \multirow[t]{2}{*}{ Virus } & \multirow{2}{*}{$\begin{array}{l}\text { Age } \\
\text { category }\end{array}$} & \multirow[t]{2}{*}{ No. } & \multirow{2}{*}{$\begin{array}{l}\text { Clinical } \\
\text { signs }\end{array}$} & \multirow{2}{*}{$\begin{array}{l}\text { Maximum } \\
\text { excretion } \\
\text { from throat }^{\mathrm{a}}\end{array}$} & \multirow{2}{*}{$\begin{array}{l}\text { Maximum } \\
\text { excretion } \\
\text { from nose }^{\mathrm{a}}\end{array}$} & \multirow{2}{*}{$\begin{array}{l}\text { Viral titer } \\
\text { in lung }\end{array}$} & \multirow{2}{*}{$\begin{array}{l}\text { Virus in extra- } \\
\text { respiratory } \\
\text { tissues }\end{array}$} & \multicolumn{5}{|c|}{ Pulmonary lesions at 4 days post inoculation } & \multirow{2}{*}{ Reference } \\
\hline & & & & & & & & $\begin{array}{l}\% \\
\text { affected lung }\end{array}$ & $\begin{array}{l}\text { Hyaline } \\
\text { membranes }\end{array}$ & $\begin{array}{l}\text { Alveolar } \\
\text { edema }\end{array}$ & $\begin{array}{l}\text { Leukocyte } \\
\text { infiltration }\end{array}$ & $\begin{array}{l}\text { Cell type } \\
\text { tropism }\end{array}$ & \\
\hline $\begin{array}{l}\text { SARS- } \\
\text { CoV }\end{array}$ & Young & 4 & No & $\begin{array}{l}10 \mathrm{e} 3.5 \\
\text { TCID50eq }\end{array}$ & $\begin{array}{l}10 \mathrm{e} 4.2 \\
\text { TCID50eq }\end{array}$ & $\begin{array}{l}10 \mathrm{e} 6.5 \\
\text { TCID50eq }\end{array}$ & No & $0-5$ & No & No & Yes & $\begin{array}{l}\text { Type I \& II } \\
\text { pneumo- } \\
\text { cytes }\end{array}$ & $(10-12)$ \\
\hline $\begin{array}{l}\text { SARS- } \\
\text { CoV }\end{array}$ & Aged & 4 & Yes & $\begin{array}{l}\text { 10e3.0 } \\
\text { TCID50eq }\end{array}$ & $\begin{array}{l}10 \mathrm{e} 3.0 \\
\text { TCID50eq }\end{array}$ & $\begin{array}{l}\text { 10e6.2 } \\
\text { TCID50eq }\end{array}$ & Kidney & $0-60$ & Yes & Yes & Yes & $\begin{array}{l}\text { Type I \& II } \\
\text { pneumo- } \\
\text { cytes }\end{array}$ & $(10-12)$ \\
\hline $\begin{array}{l}\text { MERS- } \\
\text { CoV }\end{array}$ & Young & 4 & No & $\begin{array}{l}\text { 10e5.3 } \\
\text { TCID50eq }\end{array}$ & $\begin{array}{l}10 \mathrm{e} 4.3 \\
\text { TCID50eq }\end{array}$ & $\begin{array}{l}\text { 10e4.4 } \\
\text { TCID50eq }\end{array}$ & Spleen & $0-5$ & No & $\begin{array}{l}\text { Yes } \\
\text { (small } \\
\text { amount) }\end{array}$ & Yes & $\begin{array}{l}\text { Type II } \\
\text { pneumo- } \\
\text { cytes }\end{array}$ & $\begin{array}{l}\text { This manu- } \\
\text { script }\end{array}$ \\
\hline $\begin{array}{l}\text { SARS- } \\
\text { CoV-2 }\end{array}$ & Young & 2 & No & $\begin{array}{l}10 \mathrm{e} 1.8 \\
\text { TCID50eq }\end{array}$ & $\begin{array}{l}10 \mathrm{e} 2.4 \\
\text { TCID50eq }\end{array}$ & $\begin{array}{l}\text { 10e4.0 } \\
\text { TCID50eq }\end{array}$ & $\begin{array}{l}\text { Ileum, colon, } \\
\text { tonsil }\end{array}$ & $0-10$ & Yes & Yes & Yes & $\begin{array}{l}\text { Type I \& II } \\
\text { pneumo- } \\
\text { cytes }\end{array}$ & $\begin{array}{l}\text { This manu- } \\
\text { script }\end{array}$ \\
\hline $\begin{array}{l}\text { SARS- } \\
\text { CoV-2 }\end{array}$ & Aged & 2 & No & $\begin{array}{l}\text { 10e2.9 } \\
\text { TCID50eq }\end{array}$ & $\begin{array}{l}\text { 10e3.7 } \\
\text { TCID50eq }\end{array}$ & $\begin{array}{l}\text { 10e3.1 } \\
\text { TCID50eq }\end{array}$ & $\begin{array}{l}\text { Ileum, colon, } \\
\text { tonsil }\end{array}$ & $0-5$ & No & No & Yes & $\begin{array}{l}\text { Type I \& II } \\
\text { pneumo- } \\
\text { cytes }\end{array}$ & $\begin{array}{l}\text { This manu- } \\
\text { script }\end{array}$ \\
\hline
\end{tabular}

${ }^{a}$ TCID50eq per $\mathrm{mL}$

${ }^{\mathrm{b}}$ TCID50eq per gram tissue 